\title{
PEMERIKSAAN PERTUMBUHAN BADAN SISWA SEKOLAH DASAR (SD) DENGAN MENGGUNAKAN METODE ANTROPOMETRI DI DESA ERETAN WETAN-INDRAMAYU
}

\author{
Fri Rahmawati ${ }^{1}$, Yovita Harmiatun ${ }^{2}$ \\ 1,2 Universitas Kristen Indonesia, Jakarta

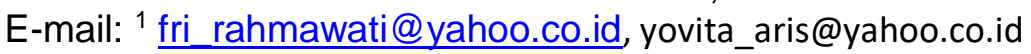

\begin{abstract}
Abstrak
Pertumbuhan merupakan suatu peningkatan ukuran fisik tubuh yang ditunjukkan dengan terjadinya penambahan jumlah dan volume sel baik secara keseluruhan atau sebagian yang dapat diukur. Banyak faktor yang mempengaruhi pertumbuhan tubuh, salah satunya adalah faktor lingkungan. Faktor lingkungan yang paling umum dan dapat dimodifikasi adalah makanan. Makanan sebagai sumber nutrisi dan zat pembangun di dalam tubuh. Nutrisi yang tidak seimbang dapat menyebabkan berbagai masalah kesehatan. Oleh karena itu pengabdian kepada masyarakat $(\mathrm{PkM})$ yang dilakukan bertujuan untuk mengetahui status gizi dari pertumbuhan para siswa Sekolah Dasar (SD) " $X$ " dan ' $Y$ " di Indramayu dalam rangkaian kegiatan PkM Fakultas Kedokteran-Universitas Kristen Indonesia di Desa Eretan Wetan, Kandanghaur-Indramayu pada tanggal 22 Februari 2020. Metode yang digunakan adalah metode antropometri yaitu pengukuran berat badan dan tinggi badan, kemudian dari hasil kedua pengukuran tersebut dihitung nilai Indeks Massa Tubuh (IMT). Berdasarkan nilai IMT yang diperoleh diketahui bahwa dari 245 siswa ditemukan 60 siswa (24.5\%) memiliki status gizi yang bermasalah yaitu mengalami kekurusan dan kegemukan. Pada siswa yang mengalami status gizi yang bermasalah, diketahui sebanyak 46 siswa (76.6\%) tergolong kurus dan 14 siswa (23.3\%) tergolong gemuk. Oleh karena itu maka perlu dilakukan identifikasi jenis dan ragam makanan yang dikomsumsi oleh siswa SD " $X$ " dan " $Y$ " di Indramayu tersebut, sehingga dapat dilakukan upaya edukasi yang tepat tentang pentingnya mengkonsumsi makanan gizi seimbang pada anak usia sekolah.
\end{abstract}

Kata Kunci: Antropometri; Pertumbuhan

\begin{abstract}
Growth is an increase in the physical size of the body indicated by an increase in the frequency and volume of cells as a whole or in part that can be measured. Many factors influence body growth, one of which is environmental factors. Environmental factors are the most common and can be modified is food. Food as a source of nutrients and building substances in the body. Imbalanced nutrition can cause various health problems. Pengabdian kepada mayarakat (PkM) which aims to see the nutritional status of the growth of " $X$ " and ' $Y$ "Elementary School students in Indramayu in a series of PKM activities at the Faculty of Medicine-Indonesian Christian University in Eretan Wetan Village, Kandanghaur Indramayu on February 22, 2020. The method used is the anthropometric method, namely the measurement of body weight and height, then from the measurement results the value of the Body Mass Index (BMI) is calculated. Based on the BMI value obtained, it is known that out of 245 students, it was found that 60 students $(24.5 \%)$ had a problematic nutritional status, namely experiencing thinness and obesity. Among students with problematic nutritional status, it was found that 46 students (76.6\%) were classified as thin and 14 students $(23.3 \%)$ were classified as fat. Therefore, it is necessary to identify the types and varieties of food consumed by the SD " $X$ " and " $Y$ " students in Indramayu, so that proper educational efforts can be made about the importance of consuming balanced nutritional foods for school age children.
\end{abstract}

Keywords: Anthropometry; Growth 


\section{PENDAHULUAN}

Status gizi merupakan salah satu parameter untuk mengetahui tingkat kesehatan seseorang. Berbagai usaha peningkatan status gizi masyarakat telah dilakukan, karena status gizi terutama pada anak sekolah merupakan salah satu faktor yang menentukan kualitas sumber daya manusia. Anak usia sekolah merupakan investasi bangsa, karena generasi penerus. Tumbuh kembangn anak usia sekolah yang optimal tergantung pemberian nutrisi dengan kualitas dan kuantitas yang benar (Bertalina, 2013). Asupan gizi anak usia sekolah di beberapa wilayah Indonesia sangat memprihatinkan, asupan gizi yang baik setiap hari dibutuhkan agar anak pada usia sekolah memiliki pertumbuhan, kesehatan dan kemampuan intelektual yang lebih baik.

Pertumbuhan adalah penambahan jumlah dan besar (volume) sel tubuh yang dilihat dari berat badan, tinggi badan, dan lingkar kepala. Setiap anak melewati proses tumbuh kembang sesuai dengan tahapan usianya, namun banyak faktor yang mempengaruhi proses tersebut di antaranya adalah faktor genetik dan lingkungan (Wong dkk., 2008). Pertambahan jumlah dan besarnya sel adalah sebagai akibat dari proses pembelahan sel. Pertumbuhan dalam pengertian pertambahan jumlah sel memiliki batas waktu tertentu. Asupan gizi yang baik dan cukup sangat dibutuhkan dalam tumbuh kembang anak, terutama pada anak usia sekolah.

Asupan zat gizi dapat diperoleh dari berbagai zat gizi, salah satunya adalah senyawa makronutrien. Makronutrien merupakan zat gizi yang dibutuhkan oleh tubuh dalam jumlah besar dan sebagian besar berperan sebagai sumber energi seperti karbohidrat protein dan lemak. (Almatsier, 2010). Makronutrien menjadi bahan bakar utama bagi manusia yang apabila dioksidasi dapat diubah menjadi $\mathrm{CO}_{2}$, $\mathrm{H}_{2} \mathrm{O}$ dan membebaskan sejumlah energi dalam sel melalui pemindahan elektron $\mathrm{ke}_{2}$. Energi dari hasil oksidasi tersebut dapat menghasilkan panas dan adenosin trifosfat (ATP) sebagai energi, sedangkan $\mathrm{CO}_{2}$ dibawa ke paru-paru lalu dikeluarkan dan air dikeluarkan melalui urin (Marks dkk., 2000). Selain makronutrien, tubuh juga membutuhkan zat gizi mikronutrien yaitu vitamin dan mineral. Vitamin merupakan nutrien organik esensial yang dibutuhkan oleh tubuh dalam jumlah kecil untuk proses metabolisme sel agar tumbuh dengan normal dan melakukan beberapa fungsi biokimia lainnya seperti sebagai zat pengatur metabolisme untuk menghasilkan energi dari lemak dan karbohidrat, serta terlibat dalam pembentukan tulang dan jaringan. Mineral sama seperti vitamin, dibutuhkan oleh tubuh dalam jumlah kecil namun bersifat sangat esensial bagi tubuh (Bintang, dkk, 2020). Semua zat gizi baik makronutrien maupun mikronutrien dibutukan oleh tubuh sesuai porsi masing-masing dari zat gizi tersebut bagi tubuh, sehingga bila terjadi status gizi tidak seimbang maka dapat menyebabkan berbagai masalah kesehatan.

Berdasarkan data World Health Organization (2015) diketahui bahwa angka prevalensi kekurusan anak di dunia sekitar $14,3 \% .1$ Kekurusan yang terjadi pada anak berhubungan dengan asupan gizi pada anak. Menurut data Riset Kesehatan Dasar (RISKESDA) tahun 2013 diketahui bahwa masalah gizi pada anak prasekolah dan anak sekolah masih cukup tinggi, hal tersebut dapat diketahui dari status gizi anak umur 5-12 tahun (menurut IMT/U) di Indonesia, yaitu prevalensi kurus adalah $11,2 \%$, terdiri dari $4 \%$ persen sangat kurus dan $7,2 \%$ kurus.

Status gizi yang baik mempengaruhi proses pertumbuhan dan perkembangan anak, agar meningkatkan kemampuan intelektual yang berdampak pada prestasi belajar di sekolah. Salah satu cara untuk menilai status gizi adalah dengan menggunakan antropometri. Antropometri adalah ilmu yang mempelajari berbagai ukuran tubuh manusia. Ukuran yang sering digunakan adalah berat badan dan tinggi badan. Selain berat badan dan tinggi badan, pengukuran tubuh yang sering dilakukan adalah mengukuran lingkar lengan atas, lapisan lemak bawah kulit, tinggi lutut, lingkar perut, dan lingkar pinggul (Supariasa dkk., 2002). Antropometri merupakan salah satu metode yang dapat dipakai secara universal, tidak mahal untuk mengukur ukuran, bagian, dan komposisi tubuh manusia. Aplikasi antropometri dapat dipakai untuk menilai status pertumbuhan, status gizi dan obesitas (Sari, 2018). 
Salah satu daerah di Indramayu yang menurut data dari Dinas Kesehatan Kabupaten Indramayu (2019) diketahui bahwa anak-anak di daerah tersebut mengalami kegagalan perkembangan dan pertumbuhan badan (stunting) adalah Desa Eretan Wetan di Kecamatan Kandanghaur, sedangkan diketahui bahwa mayoritas masyarakat di daerah tersebut berprofesi sebagai nelayan. Oleh karena itu penelitian pada rangkaian kegiatan PkM FK-UKI di Desa Eretan Wetan, Kandanghaur-Indramayu bertujuan mengetahui status gizi dari pertumbuhan para siswa SD " $X$ " dan " $Y$ " di Desa Eretan Wetan, KandanghaurIndramayu.

\section{METODE}

Penelitian yang dilakukan dalam rangkain kegiatan PkM FK-UKI di Desa Eretan Wetan, Kandanghaur-Indramayu pada tanggal 22 Februari 2020 menggunakan metode penelitian deskriptif. Subyek populasi yang digunakan adalah siswa-siswa SD "X" dan " $Y$ " dengan lokasi sekolah tersebut saling berdekatan di Desa Eretan WetanIndramayu yang hadir pada saat kegiatan PkM tersebut. Sampel pada penelitian yang dilakukan berjumlah sebanyak 245 orang siswa. Pengumpulan data diperoleh dengan melakukan dua pengukuran yaitu pengukuran berat badan dalam satuan kilogram (Kg) memakai timbangan badan dan pengukuran tinggi badan dalam satuan meter $(\mathrm{m})$ memakai alat Microtoise staturmeter untuk menentukan indek massa tubuh (IMT).

\section{HASIL DAN PEMBAHASAN}

Penelitian telah dilakukan pada siswa kelas 1-6 di SD " $X$ " dan "Y" Desa Eretan Wetan, Kandunghaur-Indramayu dengan rentang usia antara 6-15 tahun. Besar sampel dalam penelitian yang dilakukan berjumlah 245 orang siswa, distribusi sampel berdasarkan jenis kelamin dapat dilihat pada Tabel 1.

Tabel 1 Distribusi Sampel Berdasarkan Jenis Kelamin

\begin{tabular}{ccc}
\hline $\begin{array}{c}\text { Jenis } \\
\text { kelamin }\end{array}$ & $\begin{array}{c}\text { Jumlah } \\
\text { (orang) }\end{array}$ & $\begin{array}{c}\text { Frekuensi } \\
(\%)\end{array}$ \\
\hline Laki-laki & 126 & 51.43 \\
Perempuan & 119 & 48.57 \\
\hline
\end{tabular}

Berdasarkan Tabel 1 diketahui karakteristik sampel penelitian menurut jenis kelamin diperoleh bahwa dari 245 orang siswa yang menjadi sampel penelitian, sebanyak 125 orang (51.43\%) laki-laki dan sebanyak 119 orang (48.57\%) adalah perempuan.

Tabel 2 Hasil Penilaian Status Gizi Sampel Penelitian Menurut Standar WHO 2007

\begin{tabular}{ccccccccc}
\hline \multirow{2}{*}{ Umur (Tahun) } & \multicolumn{7}{c}{ Jenis Kelamin } & Frekuensi \\
\cline { 2 - 7 } & \multicolumn{7}{c}{ Laki-laki } & \multicolumn{5}{c}{ Perempuan } & (Orang) \\
\cline { 2 - 7 } & Kurus & Normal & Gemuk & Kurus & Normal & Gemuk & \\
\hline 6 & 0 & 2 & 0 & 0 & 2 & 0 & 4 \\
7 & 6 & 13 & 1 & 0 & 16 & 1 & 37 \\
8 & 4 & 17 & 1 & 1 & 12 & 3 & 38 \\
9 & 3 & 12 & 1 & 3 & 10 & 0 & 29 \\
10 & 2 & 9 & 1 & 3 & 18 & 1 & 34 \\
11 & 13 & 15 & 1 & 2 & 24 & 2 & 57 \\
12 & 1 & 13 & 1 & 3 & 15 & 0 & 33 \\
13 & 5 & 3 & 1 & 0 & 1 & 0 & 10 \\
14 & 0 & 1 & 0 & 0 & 1 & 0 & 2 \\
15 & 0 & 0 & 0 & 0 & 1 & 0 & 1 \\
\hline Frekuensi & 34 & 85 & 7 & 12 & 100 & 7 & 245 \\
\hline Persentase (\%) & $(26.98)$ & $(67.46)$ & $(5.56)$ & $(10.08)$ & $(84.03)$ & $(5.88)$ & $(100)$ \\
\hline
\end{tabular}


Pengukuran berat badan $(\mathrm{Kg})$ dan tinggi badan $(\mathrm{m})$ dilakukan untuk menghitung nilai Indeks Massa Tubuh (IMT). Nilai IMT yang diperoleh dapat digunakan dalam menentukan status gizi sampel penelitian. Berdasarkan standar penilaian status gizi anak usia 6-18 tahun menurut WHO (2007) maka diperoleh status gizi siswa-siswa di SD " $X$ " dan " $Y$ " Desa Eretan Wetan, KandanghaurIndramayu seperti terlihat pada Tabel 2.

Berdasarkan jenis kelamin (Tabel 2) dapat diketahui dari 126 orang siswa laki-laki yang menjadi sampel penelitian, sebanyak 34 orang (26.98\%) dinyatakan kurus, 85 orang $(67.46 \%)$ normal dan 7 orang $(5.56 \%)$ adalah gemuk, sedangkan dari 119 orang siswa perempuan di kedua SD tersebut diketahui 12 orang $(10.08 \%)$ kurus, 100 orang (84.03\%) normal dan hanya 7 orang $(5.88 \%)$ gemuk.

Salah satu masalah kesehatan yang sering diderita oleh anak usia sekolah adalah status gizi. Status gizi pada anak dikatakan bermasalah bila anak memiliki badan kurus atau gemuk. Menurut data WHO (2014) sebanyak 51 juta anak-anak di seluruh dunia memiliki statu gizi kurus dan sebanyak 42 juta anak mengalami kasus kegemukan atau obesitas. Masalah gizi tersebut juga banyak dihadapi oleh anak-anak indonesia, yaitu kelebihan gizi (kegemukan) dan kekurangan gizi (kekurusan), dari hasil penelitian ditemukan bahwa dari 245 orang sampel penelitian diketahui 60 orang siswa mengalami masalah gizi yaitu sebanyak 46 orang berbadan kurus dan 14 orang berbadan gemuk (Tabel 3 ).

Berdasarkan Tabel 3 diketahui bahwa sebagaian besar siswa yang mengalami kekurusan adalah siswa berjenis kelamin laki-laki yaitu sebanyak 34 orang (56.67\%), sedangkan siswa perempuan yang mengalami kekurusan hanya 14 orang (23.33\%). Selain mengalami kekurusan, di sekolah tersebut juga ditemukan siswa yang mengalami masalah gizi lebih (kegemukan). Dari hasil penelitian diketahui dari 60 orang siswa yang mengalami masalah gizi ditemukan sebanyak 14 orang mengalami kegemukan, siswa laki-laki dan perempuan yang mengalami kegemukan masing-masing sebanyak 7 orang. Anak laki-laki lebih ramping dari pada anak perempuan, meskipun memiliki IMT yang sama (HyeongGeun, 2011). Perempuan lebih cenderung mengalami kegemukan dibandingkan laki-laki karena perempuan umumnya memiliki persentase lemak tubuh yang lebih tinggi dibandingkan lakilaki (Demerath, 2007). Terdapat hubungan antara jenis kelamin dengan kejadian obesitas sentral pada usia dewasa (Puspitasari, 2018).

Tabel 3 Masalah status gizi (kegemukan dan kekurusan) pada berbagai usia

\begin{tabular}{|c|c|c|c|c|c|}
\hline \multirow{3}{*}{ Umur (Tahun) } & \multicolumn{4}{|c|}{ Masalah Status Gizi } & \multirow{3}{*}{$\begin{array}{l}\text { Frekuens } \\
\text { (orang) }\end{array}$} \\
\hline & \multicolumn{2}{|c|}{ Kurus } & \multicolumn{2}{|c|}{ Gemuk } & \\
\hline & Laki-laki & Perempuan & Laki-laki & Perempuan & \\
\hline 6 & 0 & 0 & 0 & 0 & 0 \\
\hline 7 & 6 & 0 & 1 & 1 & 8 \\
\hline 8 & 4 & 1 & 1 & 3 & 9 \\
\hline 9 & 3 & 3 & 1 & 0 & 7 \\
\hline 10 & 2 & 3 & 1 & 1 & 7 \\
\hline 11 & 13 & 2 & 1 & 2 & 18 \\
\hline 12 & 1 & 3 & 1 & 0 & 5 \\
\hline 13 & 5 & 0 & 1 & 0 & 6 \\
\hline 14 & 0 & 0 & 0 & 0 & 0 \\
\hline 15 & 0 & 0 & 0 & 0 & 0 \\
\hline Frekunsi & 34 & 12 & 7 & 7 & 60 \\
\hline Persentase (\%) & $(56.67)$ & (20.00) & $(11.67)$ & $(11.66)$ & $(100)$ \\
\hline TOTAL & \multicolumn{2}{|c|}{$46(76.67 \%)$} & \multicolumn{2}{|c|}{$14(23.33 \%)$} & $60(100 \%)$ \\
\hline
\end{tabular}


Berdasarkan umur (Tabel 3), diketahui bahwa siswa berbadan kurus ditemukan paling banyak pada anak usia 11 tahun berkelamin laki-laki yaitu sebanyak 13 orang, sedangkan siswa yang berbadan gemuk paling banyak ditemukan pada siswa perempuan umur 8 tahun yaitu sebanyak 3 orang. Menurut ElHazmi (2020) obesitas secara signifikan lebih banyak pada wanita dibandingkan pria pada semua kelompok usia. Anak berbadan kurus maupun anak berbadan gemuk sama-sama memiliki resiko yang cukup serius. Anak-anak yang mengalami kelebihan berat badan cenderung tetap mengalami kegemukan atau obesitas hingga dewasa, sehingga memiliki kemungkinan besar mengalami penyakit tidak menular seperti diabetes dan penyakit kardiovaskuler pada usia yang lebih muda (Sartika, 2011). Sedangkan anak berbadan kurus biasanya memiliki imunitas yang rendah sehingga sangat mudah terserang penyakit. Oleh karena itu baik gizi kurang maupun gizi berlebih pada anak-anak dalam usia pertumbuhan sama-sama memiliki resiko yang tidak baik bagi kesehatan.

\section{SIMPULAN}

Berdasarkan pemantauan status gizi anak siswa SD " $X$ " dan " $Y$ " di Desa Eretan Wetan, Kandanghaur - Indramayu ditemukan sebanyak 60 orang siswa mengalami masalah gizi yaitu sebanyak 46 orang siswa mengalami kekurusan dan 14 orang siswa mengalami kegemukan. Berdasarkan hasil tersebut maka perlu dilakukan identifikasi jenis dan ragam makanan yang dikomsumsi oleh siswasiswa di kedua SD tersebut, sehingga dapat dilakukan upaya edukasi (penyuluhan) yang tepat tentang pentingnya mengkonsumsi makanan gizi seimbang pada anak-anak usia sekolah yang masih dalam pertumbuhan terhadap para orang tua siswa-siswa tersebut.

\section{UCAPAN TERIMA KASIH}

Ucapan terima kasih disampaikan kepada Lembaga Penelitian Pengabdian
Masayarakat (LPPM) Fakultas Kedokteran Universitas Kristen Indonesia (UKI) yang telah memfasilitasi terlaksanaanya rangkaian kegiatan PkM yang dilakukan, serta terima kasih juga peneliti sampaikan kepada LPPM Pusat UKI yang telah menfasilitasi peneliti dalam menerima anggaran dana dari UKI.

\section{REFERENSI}

Almatsier S. 2010. Prinsip Dasar IImu Gizi. Jakarta: PT Gramedia Pustaka Utama.

Bertalina. 2013. Faktor-faktor yang berhubungan dengan status gizi anak usia sekolah (6-12 tahun). Jurnal Keperawatan. 9 (1): 5-12.

Bintang M, Rahmawati F, Safira UM, Adrianto D. 2020. Biokimia Fisik. Bogor: IPB-Press.

Demerath EW, Sun SS, Rogers N, Lee M, Reed D, Choh AC, Couch W, Czerwinski, SA, Churnlea WC, Siervogel RM, Towne B. 2007. Anatomical patterning of visceral adipose tissue: race, sex, and age variation. Obesity. 15: 2984-2993.

Dinas Kesehatan Kabupaten Indramayu. 2019. Sepuluh Desa Kabupaten Indramayu dapat Intervensi Penanganan Stunting. https://mediaindonesia.com/read/d etail/219757-10-desa-kabupatenindramayu-dapat-intervensipenanganan-stunting. [Diakses pada 13 Februari 2020]

El-Hazmi MAF, Warsy AS. 2020. Relationship between Age and the Prevalence of Obesity and Overweight in Saudi Population. Bahrain Medical Bulletin. 24 (2): 17.

HyeongGeun $\mathrm{P}$, KeeHo $\mathrm{P}$, Myung HK, Gyo SK, Sochung C. 2011. Gender Differences in Relationship between Fat-Free Mass Index and Fat Mass Index among Korean Children Using Body Composition Chart. Yonsei Med J. 52 (6): 948952. 
Marks DB, Marks AD, Smith CM. 2000. Biokimia Kedokteran Dasar : Sebuah Pendekatan Klinik. Penerbit Buku Kedokteran EGC.

Puspitasari N. 2018. Faktor kejadian obesitas sentral pada usia dewasa. Higeia journal of public health research and development. 2 (2): 249-259.

Riset Kesehatan Dasar. 2013. Jakarta. https://www.kemkes.go.id/resource s/download/general/Hasil\%20Riske sdas\%202013.pdf [Diakses pada 11 Februari 2020].

Sari DY, Dewanto WK, Surateno S. 2018. Aplikasi pemantauan status gizi berdasarkan pengukuran antropometri menggunakan metode Fuzzy Logic. Jurnal Teknologi Informasi dan Terapan. $5(1)$ : 55-64.
Sartika RAD. 2011. Faktor risiko obesitas pada anak 5-15 tahun di Indonesia. Makara, Kesehatan. 15 (1): 37-43.

Supariasa, I Dewa Nyoman, dkk.. 2002. Penilaian Status Gizi. Jakarta: EGC.

Wong DL, Hockenberry-Eatom M, Wilson $D$, Winkelstein ML, Schwartz $P$. 2008. Buku ajar keperawatan pediatrik. Jakarta: EGC.

WHO. 2007. Reference 2007 for Child and Adolescent. WHO, Geneva.

WHO. 2015. The world bank joint child malnutrition estimates.. http://apps.who.int/gho/data/view.m ain.NUTUNUNDERWEIGHTV?lang =en [Diakses pada 11 Februari 2020] 